\title{
The Role of ICT to Develop Early Literacy of Children in Era Digital
}

\author{
Lathifatul Fajriyah, Puji Fauziyah \\ Yogyakarta State University, Yogyakarta, Indonesia \\ e-mail: lathifatul_fajriyah2016@student.uny.ac.id
}

\begin{abstract}
The purpose of this research is to know the development of digital diary literacy through ICT. This study will discuss the importance of ICT in children and children's literacy in the digital age. The method used is qualitative with the type of literature study where the data is taken from library resources such as books, journals, articles, and other relevant resources. In this study found that the role of ICT is very useful for children especially developing literacy. The use of ICT in children needs to get guidance from adults so that benefits can be achieved, in addition, adults need to give confidence in children as competent users to make children more explorative to use ICT.
\end{abstract}

Keywords: ICT, early literacy development, digital literacy

\section{INTRODUCTION}

Literacy is an important development for the future of children. Rogers (2011) argues that literacy can no longer be defined in reading and writing only but also includes computers and digital literacy to prosper all layers of society better in the information age. in this era which is all digital requires children to be able to master science so that they need literacy skills to understand it. However, the use of technology, especially ICT in children, still has a continuous limit.

Some studies have tried to investigate the role of ICT for children. some of them agreed and refused. Cordes and Miller (2000) the use of ICT in learning and playing must be eliminated. The refusal is due to disturbing aspects of child development that must be developed. Similar opinion by Fomichova and Fomichov (2000) children in developed countries spend more time using computers than with families. The family is the first environment for children to know the world. A closeness between children and parents can have a major influence on the development and growth of children, including the development of literacy in children.
However, in the study (Haugland, 1992) found that children who have experience in ICT can improve children's development and skills such as verbal and non-verbal, problem-solving, long-term memory abstraction, and structural knowledge. Another study by Van Scoter \& Boss (2002) ICT can provide a rich contribution to children's literacy in four areas, namely speaking, listening, reading, and writing. The above study is only part of the other side of the impact of technology and literacy. Most studies discuss the impact of computers on social children, however, this study will discuss the role of technology in children's literacy which is very useful in the future of children. Therefore, this study provides information that ICTs and literacy are important to be taught early together along with wise use for children.

\section{METHOD}

The method used is descriptive qualitative with literature study design where data is taken from various sources such as books, journals, articles and other relevant sources. Researchers will compare several data to determine the role of ICT in child literacy. 


\section{RESULT AND DISCUSSION}

Today technology is something that cannot be separated from everyday life. Young people and adults use technology more often to communicate and play than direct interaction with others. ICT has an effect on the environment of children and even get support and interest from various education sectors to develop and integrate ICTs in policies, curricula, and educational practices (Bostald, 2004). Based on data from common sense Media organization (2014) the use of tablets in children increased $40 \%$ from $8 \%$ in just two years and increased by $75 \%$ from $50 \%$ in the use of tablets and smartphones rather than watching TV. From these data shows technology has entered the world of children. the use of mobile phones and tablets which are part of ICT requires literacy skills to be able to use them. Child literacy and technology are issues that are still much debated. The advantages and disadvantages of technology depend on how children use it and supervision of adults. Many programs that can be easily accessed that are not properly watched by children. so that this needs special attention so that children can be wise in using ICT.

\subsection{ICT for children}

ICT according to Elston (2007) ICT as the technology used to manage information and aid communication. While ICT in UNESCO (2003) ICT generally relates to the technologies that are used for accessing, gathering, manipulating and presenting or communicating information. Nowadays, children prefer to play gadgets or computers than books, because gadgets and computers are more accommodating to various things and comfortable to play. so that children's knowledge of technology is needed to get broader knowledge.

According to Siraj-Blatchford, I, and SirajBlatchford, J. (2000) that DATEC (developmentally appropriate technology in early childhood) has made seven general principles for the use of technology by young children that can be used by parents, namely:

1. Ensure educational goals

2. Encourage collaboration

3. Interact with other aspects of the curriculum

4. Ensure the child is in control

5. Choosing a transparent application

6. Avoid applications that contain violence and stereotypes
7. Be aware of health and safety issues.

According to Healey (1998), ICT is not suitable for early childhood under 7 years, because children need verbal interaction with other humans, besides computers, do not teach intersensory children who can reduce other developmental tasks. Miller (2005) states that some people think that new technology is a distraction from activities that are more natural, healthy, and in accordance with developments, or cause concern that can access inappropriate content, endanger safety through online relationships. Dakin and Chung (2011) in their study have studied 1000 students in 10 different countries who use technology for 24 hours which can make students feel frustrated, lonely, anxious and heart palpitations. These theories essentially have the same opinion that makes children passive, because the world of children is a world of play that is fun with friends so that the existence of it is rejected for the sake of health, safety, and a healthy childhood.

In accordance with the principle of using ICT above, accompanying children when using technology devices is very important, so that children are wise in using them. There is a sense of concern for parents when they let their children play gadgets and computers to open up happy information for children's growth and development. This concern will limit children's creativity. Everyone can access any information to get knowledge easily including children. in era digital, technology, especially computers and mobile phones, is equipped with several applications that can make it easier for children to play and learn. So parents need to give confidence to children as competent users so that children's creativity increases.

Welch (1995) 40\% of children have access to computers and parents let their children use computers frequently in America. According to (Toomey, 2013; Ling, 2000; Srivasta, 2005) ICT can cause dependency that can reduce achievement and discipline in children which eliminates school education goals. Children feel anxious, worried, and lonely which can ultimately affect their academic performance and achievements. This is not in accordance with the principle of using ICT by children. Parents should limit the use of ICT in children. provide control even assistance to collaborate with children when using technology so that things that are feared do not happen and children can use technology wisely. 
Shimbun (2008) cited Ishii (2011) notes that in a year around 1,000 children are involved in rape and other crimes, violence, and obscene images are only a few clicks away. In some ways, obscene images and streams of video show pictures that lead to threatening or breaking up, children are active learners who have great curiosity. When a child cannot read, the child will choose the mark or picture. This is the duty of parents to provide educational programs which are in accordance with the principles of using ICT for children, if this happens it can affect a child psychologically because the child's memory absorbs more quickly when they practice.

Parental anxiety and the impact of the child it received attention from UNICEF to review the global evidence available on children's online protection including Child Safety Online reports (Unicef Office of Research, 2011) with a focus on children sex abuse recorded in pictures, and care for people young people for sex. It is very important that adults provide assistance when children use technology. because of the nation's moral decadence, one of them is caused by the sophistication of misused technology.

\subsection{Technology and Early Literacy Children}

There is a new term in the world of literacy, namely new literacy, and old literacy. New literacy is a printed text which is then developed with new technologies that use networks such as the internet and the web (Lanksheardan Knobel, 2006; Davies and Merchat, 2009). New literacy has transformed visuals into audiovisual and graphics. ORT devices ('Oxford Reading Tree') are one of the technoliteracy devices that use audio-visual learning that can introduce written words. Word planting, written and phonological awareness. This device is more attractive to many children than traditional ones (Karemaker, Pitchford, \& O'Malley; 2010). This specialization is sometimes wasted by parents by not guiding them so they spend more free time with games or online or via text messages.

Digital literacy has been discussed by several different disciplines and professionals from different perspectives. Multi integrated perspectives from the definition of digital literacy or literacy have not yet emerged (Myers, Erickson and small, 2013). In Marsh, Hannon, Lewis and Ritchie's (2015) research suggests that in the 21 st century, emerging digital literacy practices were developed in multilingual, multimodal and multimedia communicative actions. In the ICT there are pictures, words, and sounds together that can help children communicate their ideas, thoughts, and feelings. Parents and teachers can help children use it so as to gain complex knowledge about the ways in which communication occurs in the digital world. The International Early Childhood Education Association has a mission to promote and support optimizing education and development of children from birth to early adolescence to the wider community that fosters the professionalism of educators and efforts to care for children in the wider community (McKie \& Butty, 2011). Ensuring children get the early skills and awareness they need to become successful readers and writers is very important (Rohde, 2015). This opinion shows that literacy learning is important and very appropriate when taught in early childhood.

According to Genloot (2013) ICT can help children to learn to read more easily because writing is clearer and they can use the keyboard to comment on other writings so that they can be read by other friends than using a pencil. Many studies have been shown that texts and new technologies are embedded within many young children 's lives (Marsh: 2004). for example pretending to send text messages from their parents' phones, as has been identified in previous studies (Marsh et al., 2005). it can be seen that this engagement with a range of contemporary children and contributing to our understanding of emergent techno-literacy. These practices should be valued and the place they play in the development of children as competent users and producers of media texts and acknowledged in curriculum frameworks for the early years. Literacy as skills development is embedded within children 's techno-literacy practices, whether that is related to learning, phoneme relationships, or reading text on the screens of computer games. (Mars: 2004).

According to Lukas and Peter (1997), the importance of literacy for children to be a good reader is solving written codes, being able to understand and compile text in the form of writing, visual and verbal meaning, using text functionally, and being critical. Some multimedia language programs can support several aspects of a child's early literacy such as vocabulary, reading, and writing. symbols contained in multimedia can help them express writing that has meaning (Segers \& Verhoeven, 2002). 
In Contras, Toomey (2013) states that digital technology can have a detrimental effect on students' focus and learning behavior and hence becomes a risk factor for ICT in the learning environment. The use of ICT in children is more in games or viewing videos that make ICT learning content disappear. However, this is not entirely a negative effect, when children see videos, children learn language by understanding the meaning of the images and sounds in the video and even their expressions. because literacy is not only an act of reading and writing but also understanding language (Unesco, 1992).

According to Alaba (2011), Some problems with techno-literacy are lack of discipline, examination of mall practices and cellular bullying. When a child can read and write allows the child to try to comment on other writings. The practice mall in question is as a practice of opening pornographic sites. Children have great curiosity so they explore knowledge by trying various things to gain knowledge. Literacy ability according to Chomsky is an innate ability from birth, children can construct their own writing (Crain, 2015). In it such as computers and iPad in its use, there are several steps that must be understood by children so that literacy skills are needed. Children can easily operate themselves because of high curiosity. However, its use is not necessarily true because it could accidentally open programs that could damage children's development. therefore, guidance from adults and parents is needed so that children use ICT accurately.

Based on early childhood learning according to Vygotsky must be adapted to the culture. ICT development is one of the cultural developments that must be introduced to children as well as according to the principles of using ICT for children. This is a change that provides challenges for children. According to Donohue (2015) in his study observing children playing using digital technology and finding that there were observation, exploration and creation and drawing. This shows that ICT is safe to use by children and can develop children's literacy.

\section{CONCLUSION}

Technology is common for today's children. facilitating and assisting children using ICT is very important. teach techno-literacy aims to facilitate children in exploring ICT that is full of coding. Actually, the problem about ICT is not because of its use but the information is chosen. The negative of it is malpractice, pornography, games, and music. providing guidance is very important to maintain health and wisdom in using it. in future studies are expected to be able to research more specifically about technologies such as youtube and online games that can affect children's development. because children now use more youtube applications to view videos and other information and online games as learning. In addition, the literacy in the study is still too broad so that many discussions are presented. Parents need to give children restrictions using ICT, such as encouraging physical and mental activities as a whole so that children's development can develop as they should.

\section{REFERENCES}

[1] Alaba S.O. (2011), Mobile Phone Adoption, Its Influence on Social Behavior, Schooling and Academic Work of Adolescent Students in Osun State, Nigeria, Malaysian Journal of Educational Technology, 11(1), pp. 35-43.

[2] Bolstad, R. (2004). The role and potential of ICT in early childhood education: A review of New Zealand and international literature. Wellington: Ministry of Education.

[3] Crain, W. (2015). Theories of Development: Concepts and Applications: Concepts and Applications. Psychology Press.

[4] Common Sense Media. (2013). Zero to eight: children's media use in america 2013. A CommonSense Research Study. Retrieved from https://www.commonsensemedia.org/research/z ero-to-eight-childrens-media-use-in-america2013.

[5] Cordes, C., \& Miller, E. (2000). Fool's Gold: A Critical Look at Computers in Childhood. Accessed 28 july 2018

[6] Davies J and Merchant G (2009) Web 2.0 for Schools: Learning and Social Participation. New York: Peter Lang.

[7] Donohue, C (2015) Technology \& Digital media in the early years: Tools for teaching and learning, Routledge \& NAEYC

[8] Dakin, P., Chung, E. ( 2011). Tech addiction symptoms rife among students. CBC News .Retrieved

http://www.cbc.ca/news/technology/techaddiction-symptoms-rife-among-studet1.994827.

[9] Fomichova, O. \& Fomichov, V. (2000) Computers and the thought-producing self of the young child. British Journal of Educational Technology 31, 3, 213-220.

[10] Genlott, A. A., \& Grönlund, ^. (2013). Improving literacy skills through learning reading by writing: The iWTR method presented and tested. Computers \& Education, 67, 98-104.

[11] Haugland, S. (1992) The effect of computer software on preschool children's developmental 
gains. Journal of Computing in Childhood Education 3, 1, 15-30.

[12] Healey, J. (1998) Failure to Connect: How Computers Affect Our Children's Minds - for Better or Worse. Simon and Schuster, New York.

[13] Ishii K. (2011), Examining the adverse effects of mobile phones use among Japanese adolescents, Keio Communication Review, No 33, pp. 69-83. Retrieved from http://www.mediacom.keio.ac.jp/publication/pd f2011/04ISHII.pdf

[14] Karemaker, A., Pitchford, N. J., \& O’Malley, C. (2010). Enhanced recognition of written words and enjoyment of reading in struggling beginner readers through whole-word multimedia software. Computers \& Education, 54(1), 199208.

[15] Lankshear C and Knobel M (2006) New Literacies: Everyday Practice and Classroom Learning, 2nd edn. Maidenhead: Open University

[16] Luke, A. F., \& Peter. (1997). The social practices of reading. In P. F, Sandra Muspratt, \& Allan Luke (Eds.), Constructing critical literacies (pp. 185-225). New Jersey: Hampton Press.

[17] Marsh. J, Hannon.P,Lewis. M, and Ritchie. L., (2015) young children'sinitiation into family literacy practices in the digital age

[18] Marsh, J. (2004). The techno-literacy practices of young children. Journal of early childhood research, 2(1), 51-66.

[19] Marsh, J., Brooks, G., Hughes, J., Ritchie, L., Roberts, S., \& Wright, K. (2005). Digital beginnings: Young children's use of popular culture, media and new technologies.
[20] Meyers, E. M., Erickson, I., \& Small, R. V. (2013). Digital literacy and informal learning environments: an introduction. Learning, media and technology, 38(4), 355-367.

[21] Rogers, T. (2011). Literacy, Leadership and Marginalized Groups. In A paper presented at the 7th Pan African Reading for all Conference, held at University of Botswana, Gaborone.

[22] Rohde, L. (2015). The comprehensive emergent literacy model: Early literacy in context. SAGE Open, 5(1)

[23] Siraj-Blatchford, I., and Siraj-Blatchford, J. (2000) Reflexivity, Social Justice and Educational Research, in Scott, D. (Ed) Values in Educational Research, Bedford Way Papers, Univ. of London Institute of Education

[24] Snyder I (2001) A new communication order: Researching literacy practices in the network society. Language and Education 15(2-3): 117131

[25] Srivastava L. (2005). Mobile phones and evolution of social behavior. Behavior and Information Technology 24, 111-129.

[26] Toomey W. (2013), Using ICT In Education: Some of The Risk Factors, Retrieved from http://minnie.tuhs.org/GradDipEd/wkt_tlmy_ess ay.pdf

[27] UNICEF (2011). Child Safety Online: Global challenges and strategies, Florence: UNICEF.

[28] Van Scoter, J. \& Boss, S. (2002) Learners,Language, and Technology: Making Connections that Support Literacy. Northwest Regional Educational Laboratory. Retrieved 30 June, 2004, from http://www.netc.org/earlyconnections/pub/index .html. 